\title{
Pearls in the COVID-19 pandemic: The case of older adults' lived experiences in Ghana
}

\author{
Delali Adjoa Dovie \\ University of Ghana - dellsellad@gmail.com
}

\begin{abstract}
This study investigates older Ghanaian adults' lived experiences of the COVID-19 pandemic along the trajectory of social, healthcare, childcare, self-care and humanitarian dimensions and how they navigated the effects thereof, utilizing interpretive methodology based qualitative dataset. The sample $[\mathrm{n}=10]$ was selected using purposive sampling technique. The paper finds that the current pandemic poses significant social challenges. The restrictions on human social movements has implications for social isolation. Social isolation can lead to loneliness and depression. Essentially, loneliness and long-term social distancing physiologically have the propensity to decrease the ability of an individual to

quence, the study participants adopted a myriad of survival strategies such as social bonding with grandchildren, keeping busy, fending for and socialising children outside the traditional classroom environment and yet keeping them focused academically. These activities facilitate social interaction among older adults and children with implication for bridging the childcare gap that the closure of schools has brought about with some form of relief for working mothers. It also serves as an income generating avenue in disguise albeit meagre. In conclusion, more reflection on and the study of the social, psychological/emotional, self-care and childcare challenge dimensions of the pandemic is imperative.
\end{abstract} fight infections and inflammations. In conse-

Keywords: older adults, COVID-19 pandemic, challenges, coping mechanisms, childcare.

\section{Pérolas na pandemia COVID-19: o caso das experiências vividas por idosos no Gana}

\section{Resumo}

Este estudo investiga as experiências vivi- vos baseados em metodologia interpretativa. das pela população idosa no Gana durante a A amostra [ $\mathrm{n}=10]$ foi selecionada usando a pandemia COVID-19, ao longo da trajetória das dimensões sociais, de saúde, de cuidado infantil, de autocuidado e humanitária e a forma como eles percorreram os seus efeitos, utilizando um conjunto de dados qualitatitécnica de amostragem intencional. O artigo conclui que a atual pandemia apresenta desafios sociais significativos. As restrições aos movimentos sociais humanos têm implicações para o isolamento social. $\mathrm{O}$ isolamen-

(c) The Author(s) 2021. Open access article published online by Interações: Sociedade e as Novas Modernidades, ISSN: 2184-3929, at https://interacoes-ismt.com, under the terms of the Creative Commons Attribution-NonCommercial 4.0 International Licence (https://creativecommons.org/licenses/ by-nc/4.0). 
to social pode levar à solidão e à depressão. Essencialmente, a solidão e o distanciamento social de longo prazo, fisiologicamente, têm a propensão de diminuir a capacidade de um indivíduo em combater infeções e inflamações. Em consequência, os participantes do estudo adotaram uma miríade de estratégias de sobrevivência, como o vínculo social com os netos, mantendo-se ocupados, cuidando e socializando as crianças fora do ambiente da sala de aula tradicional e, ainda, mantendo- -as focadas academicamente. Essas atividades facilitam a interação social entre adultos mais velhos e as crianças, colmatando a lacuna de cuidado infantil que o encerramento das escolas trouxe e aliviando as mães que trabalham. Também serve como uma forma disfarçada de gestão de rendimento, embora escassa. Em conclusão, é fundamental que haja mais reflexão e estudo das dimensões sociais, psicológicas / emocionais, do autocuidado e do cuidado infantil da pandemia.

Palavras-chave: população idosa, pandemia do covid19, desafios, mecanismos de enfrentamento, cuidados infantis.

\section{INTRODUCTION}

The novel coronavirus is one of the most recent deadliest global pandemics which has affected both developed and developing countries (Chanda-Kapata, Kapata, \& Zumla, 2020). The World Health Organisation (WHO) on 12 January 2020 officially announced that the novel coronavirus first affected the inhabitants of Wuhan City, Hubei Province, China in December 2019, caused by the severe acute respiratory syndrome of coronavirus (SARS-CoV-2). Novel coronavirus cases have shown significantly lesser mortality rates than the 2003 severe acute respiratory syndrome (WHO, 2020). Inasmuch as COVID-19 infects people age notwithstanding, there is evidence that suggests that two (2) groups of people are at a higher risk of contracting the severe COVID-19 disease namely older persons and individuals with underlying medical conditions are the most at risk groups. This study focuses on the former category of people. Further, older individuals are predisposed to diverse challenges such as neglect, maltreatment and violence, financial constraints or poverty (De-Graft Aikins, Kushitor, Sanuade, Dakey, Dovie, \& Kwabena-Adade, 2016; UN, 2020), isolation or loneliness that may complicate such a situation.

The current coronavirus disease 2019 (COVID-19) has induced various problems that up until now are insufficiently addressed, some of which are reflective of under- 
lying social and other challenges worldwide (Rothan, \& Byrareddy, 2020). In addition to medical and technological, social as well as psychological problems and underlying philosophical challenges require better addressing in order to further improve the approach to this pandemic and arguably to future pandemics and other global crises with the plight of the elderly in focus.

The COVID-19 disease was declared a pandemic by WHO on March 11, 2020 (WHO, 2020). This disease has caused a lot of havoc to human lives in diverse ways across the globe. For instance, social confinement became mandatory, affecting the entire population entailing older persons. Such confinement has affected the physical, mental, and emotional well-being of older people. These public health measures, albeit necessary, have the propensity to impact older individuals' health and wellbeing, due to the restricted face-to-face relationships with their significant others; cancellation or plans postponement; uncertainty about the future; and the potential threat that the virus may pose to themselves and their families. Essentially, the mental health impact of the economic recession cannot be ignored and may be cumulative.

Argumentatively, The Public Health Agency notes with Sweden in focus that susceptibility to the virus pertains to the fact that "high age is the main risk factor. This is shown in available studies on the outbreak of COVID-19. Therefore, those who are 70 years or older are in a risk group" (The Public Health Agency, 2020). In consequence, the Public Health Agency, which has the national responsibility for the public with the emergence of the pandemic alleged that "people over 70 need help limiting their contact with other people ... Now is the time to try to isolate them as much as possible" (Press Conference, 2020).

Yet, active ageing is the view that the negative aspects of ageing can be countered through an active lifestyle (FUTURAGE, 2011). According to Blaakilde (2007), this view in combination with the concept of 'successful ageing' makes it the duty of older people to demonstrate a high degree of activity in order to show that they are not being a burden on society. However, research has revealed that older people subjected to child-like treatments have the propensity to develop passivity, decreased independence, a withdrawal from responsibility and the acceptance of a marginalised role in society (Nilsson, Ekstam, \& Andersson, 2018; Nilsson, Ekstam, Axmon, \& Andersson, 2021). It is plausible from the previous paragraph that being categorised by state authorities as old and vulnerable could have an impact on the self-image and future health of the individuals within the targeted age group. A potential consequence that was not sufficiently considered in the discussion of how society should deal with the 
outbreak of the pandemic. Following this analogy, the fact for Foucault demonstrates that different epidemics such as leprosy, the plague, and later smallpox among others have been historically handled differently, serving as empirical examples to describe three historically different forms of exercising power. Foucault points to a gradual, but partly overlapping, shift from a sovereign force directed at the individual in premodern society, entire population in modern society, what is known today as policy, to the evocation of a new mentality, what Foucault calls "governmentality", among the citizens, through neoliberal individualisation and responsibilisation in post-modern society, where individuals take increased responsibility for governing themselves (Foucault, 2007; Sarasin, 2020).

Social distancing has come forth as one of the essential protocols guarding against the COVID-19 pandemic which encompasses measures such as avoiding crowded places and not leaving homes unnecessarily (Singu, Acharya, Challagundla, \& Byrareddy, 2020). Social distancing has been the key to flattening the curve and decreasing transmission of COVID-19. In neighbourhoods that are crowded, social distancing may not be feasible. This puts individuals living in crowded neighbourhoods at a higher risk of becoming ill with the virus, as well as increases the rate of transmission of the same. A thin line exists between trying to decrease the spread of COVID-19 and preventing the progression of economic decline. It is evident that social distancing and quarantine methods are helping to flatten the curve, however, at the expense of the country's economic stability (Singu et al., 2020). During the lockdown, nonessential workers were directed to stay at home and only go out to the grocery store or to a pharmacy if needed. Social distancing was to be followed strictly during the lockdown.

An individual's well-being base is constituted by social support. A study has showed that higher amounts of social support were associated with lower levels of atherosclerosis in women predisposed to a higher risk for CVD. IG (2020) demonstrated in a study in California that social support among Mexican adults served as a barrier against the detriments of the discrimination they encountered.

People have been running errands for the elderly who are more vulnerable to falling ill with the virus. During times of a global health crisis in which there is a call for social isolation, such as is in the case of the COVID-19 pandemic, it is important to find ways to maintain communication and social cohesion to preserve each other's well-being. 
Older people encounter challenges due to their inability to care for themselves, loneliness due to the loss of family relations including social change, the lack of spouses and children, modernisation, urbanisation, migration, multiple careers including busy work schedules (Dovie, 2019). This has significant implications for coping with the situation at hand.

Coping refers to a state of capability between the individual and the environment that allows a person to maintain a sense of well-being or satisfaction with quality of life. Coping strategies may be active, confrontational and purposeful or they may be passive, emphasising avoidance, minimisation of threat, or resignation. Adaptation refers to a range of behaviours an individual uses to meet demands namely developing habits to confront problems and to manage frustration and anxiety (Quadagno, 2014).

Three adaptive skills are especially helpful in coping with stressful life situations (Quadagno, 2014, p. 162). The first is the ability to marshal social support, which provides a buffer against stress. Second, ability to compensate for losses in social roles by substituting new roles in order to feel less lonely, remain more active and involved in relationships and find greater meaning in life. Third, ability to modify one's environment either architecturally or by moving to a more suitable home can reduce stress and enhance life satisfaction and emotional well-being.

Gender determines who gives care and who receives the same (Schatz \& Seeley, 2015). In East and Southern Africa, both men and women live with impacts of the care deficit. However, sexual division of labour has meant women predominantly fill the void in care (Oppong, 2006).

Ghana still has a high burden of infectious diseases and a very growing burden of non-communicable diseases (De-Graft Aikins \& Apt, 2016) that must also be tackled within available resources. There is an increasing burden of chronic diseases or conditions among other health challenges (Dovie, 2019) which may be compounded by the COVID-19 pandemic. That notwithstanding, little was known that less than three months into the new year of 2020, the majority of the world will be fighting the COVID-19 pandemic. This virus is causing havoc and it is not selective in whom it attaches itself to, whether poor, wealthy, an older adult, or a new-born child. Older persons and individuals who have chronic heart diseases, lung diseases, diabetes, cancer and hypertension are at higher risk for more serious COVID-19 illnesses and deaths (UN, 2020). This is because the immune systems of human beings grow weaker with age, making it more challenging for older adults to fight off infectious diseases. Further, 
chronic diseases are more common with age, with the propensity of compromising the immune system and making people more vulnerable to serious health complications. However, the advice given, and how the elderly are able to protect themselves varies between wealth and crucially, age. For many families there will be a concern about how to entertain children while also conducting and keeping up to date with schoolwork, adults' own respective work responsibilities, as well as financial worries (Marston, Musselwhite, \& Hadley, 2020).

The risk for severe illness with regard to COVID-19 increases with age, with older adults at highest risk (CDC, 2020). According to WHO (2020) COVID-19 has especially changed older adults' ability to stay socially connected and how they are perceived, lack of physical contact with other family members, etc, and other activities; and anxiety and fear of illness and death. Older persons risk being disproportionately affected by physical distancing measures, since isolation could have a serious effect on their mental health (UN, 2020). Restrictions on normal ageing is recognised, little research has been conducted or exists on the adaptation strategies used to alternate such restrictions (Hsieh, Wu, \& Tang, 2016). Further, many COVID-19- older person related studies (e.g. CDC, 2020; Musango, Nundoochan, \& Kirigia, 2020; RiveraRodrigues, \& Urdinola, 2020; Singu et al., 2020) focus on the health impacts of the disease and thus overlook socio-economic factors. There is yet to be out in Ghana, work on the resilient responses of older adults to the COVID-19 pandemic. It is on the basis of this that this study was set out to fill such a gap in the Ghanaian literature, The objective of this present study is therefore to explore older adults' lived experiences based adaptation strategies employed in coping with the effects of COVID-19 pandemic including a potential to shift the perspective on older persons from that of vulnerability and risk to strength and opportunities.

Use is made of conceptual framework comprising the framework of Engel's (1980) biopsychosocial model and Lazarus' (1993) coping theory and engaged in study design, data analysis and writing of this paper. These frameworks conceptualise mutually influential relationships between individual, biological and contextual factors as important to older people's experiences, impacts, coping, adaptation and well-being (Engels, 1980; Lazarus, 1993). These theoretical frameworks support a strength-focused approach and consideration of the multi-level factors - such as those presented in this paper - that pertain to experiences, challenges and coping among the Ghanaian older adult. 
Coping methodologies are viewed as those endeavours, both conduct and mental, that a person utilises to suppress, diminish or limit and endure distressing occasions (Sreeramareddy et al., 2007). Coping approaches are additionally categorised into emotion-focused and problem-focused coping techniques (Lazarus, 1993). Whereas emotion-focused coping techniques comprise concentrating on the positive, self-criticism, unrealistic reasoning, minding your own business, separation, and decrease in anxiety, problem-focused coping techniques consist of looking for social help.

\section{RESEARCH METHODS}

\section{Setting}

The study was conducted in Tema in the Greater Accra Region of Ghana.

\section{Design}

The study adopted interpretive phenomenology to investigate the lived experiences of Ghanaian older adults during the COVID-19 pandemic. This approach of phenomenology enabled the researcher to gain in-depth understanding of the interconnections between participants' lived experiences vis-à-vis COVID-19 pandemic impacts. Interestingly, the lived experiences are holistic and inter-related such that it is sometimes difficult to delineate one experience from the other.

\section{Target Population and Sampling}

The target population was older Ghanaian citizens who were willing to take part in the study. Persons who had experienced the COVID-19 pandemic were recruited for the study. The study was explained to all the participants and those who volunteered and met the inclusion criteria (60+, resident in Tema, experienced the COVID-19 pandemic, informed consent) were selected. Suffice it to say that per these criteria, the study participants were purposively selected.

\section{Participants and Data Collection}

Ten (10) participants were purposively selected (5 women and 5 men) through purposive sampling. Individual interviews were conducted in English, audio-taped, transcribed and analysed using thematic analysis procedures. Inform consent was obtained from all participants and rigour was ensured through prolonged engage- 
ment and member checking. The ages of the study participants ranged from 60 to 84 years, whereas their educational backgrounds ranged from middle school leaving certificate to doctorate degree level (Table 1).

\section{Table 1}

Participant demographics.

\begin{tabular}{|c|c|c|c|c|c|}
\hline Respondent & Gender & Age & Marital status & Education & Occupation \\
\hline $\mathrm{R} 1$ & Female & 75 & Married & Diploma & Retired Social worker \\
\hline $\mathrm{R} 2$ & Male & 70 & Widower & Middle School leaver & Retiree \\
\hline R3 & Female & 71 & Divorced & Middle School leaver & - Retiree \\
\hline $\mathrm{R} 4$ & Male & 65 & Married & First degree & Retiree \\
\hline $\mathrm{R} 5$ & Female & 69 & Widow & Middle School leaver & Retiree \\
\hline R6 & Female & 67 & Widow & Middle School leaver & r Retired Teacher \\
\hline R7 & Male & 84 & Widower & Doctorate degree & Retired Lecturer \\
\hline R8 & Female & 73 & Divorced & Diploma & Retired Labour officer \\
\hline R9 & Male & 75 & Married & First degree & Retiree \\
\hline $\mathrm{R} 10$ & Male & 66 & Married & First degree & Retiree \\
\hline
\end{tabular}

Source: Field data

\section{Data Collection Procedures}

The individual interviews were conducted in English. The interviews lasted between 40 to 45 minutes. In order to elicit free individual expressions, open ended questions were posed. In furtherance to that, probes were used to gain in-depth understanding of the phenomenon under investigation. The author who is experienced in qualitative interviewing collected all the data. However, the choice of location and time of interviews were at the convenience of the participants. The interviews were audio-recorded with a digital voice recorder with the consent of the participants. The ten (10) interviews were conducted in this study between March and October, 2020. The interviews were transcribed verbatim and field notes were written on context and non-verbal behaviour during the interviews. Reflections during data collection were also written as part of field notes to ensure that the views of the participants of the study were duly represented. The study was conducted at individual participants' homes and/or chosen locations in Tema.

The researcher's positionality and subjectivity including the participants' shaped the epistemological process, and to some extent obfuscating the notion of voice in the presentation of data. Sharing of knowledge is an integral aspect of the research process in this paper including the demonstrations of how the data are meaningful, 
appeal to diverse audiences and engage stakeholders in the relevance of the study. The use of voices/quotations or texts depict an interpretation of findings. This in fact is the researcher's way of acknowledging that the voices of researcher's and the research participants are not the same. However, they are interconnected. In essence, the material generated in this paper are co-constructions, representations of interactive processes between the researcher and research participants.

Incorporating the voices of the researcher with those of the research participants in the process of dissemination is a significant component of the qualitative research process. Structurally, the paper stresses and honours the participants' own voices as generative of meaning and knowledge in the presentation of this qualitative research write up. This style of dissemination effort is reminiscent of the positionality of the researcher in relation to choosing what to be included or not.

\section{Data Management and Analysis}

In this study, concurrent data analysis was undertaken following the processes of qualitative analysis proposed by Collaizzi's (1998) phenomenological method in seven distinct stages: the audio-taped data were transcribed. Thereafter, the transcripts were (1) read and re-read to fully understand the lived experiences of the participants. The transcripts were coded and similar codes were grouped together. The author including an independent person coded the data independently, after which differences were discussed in order to ascertain a consensus on the most appropriate code for a piece of data. Using thematic analysis, they systematically coded all data and then organised the codes, based on some similarity, into larger and larger categories that may lead to a hierarchical structure of codes and subthemes. Themes, along with supporting excerpts from the data, are presented in the final report, including description of those themes in relation to the research questions. (2) Significant descriptions were extracted from the transcribed interviews of identified phrases or sentences that were directly related to the participants' COVID-19 pandemic experiences. (3) The meaning of each significant statement were outlined. (4) The first three steps for each description, and creation of themes based on which formulated meanings of the descriptions were repeated. Two independent persons from Tema were purposively recruited to develop themes generated in the study. Further, generated themes and sub-themes were discussed and discrepancies were resolved by going back to the data and making sure that the theme and sub-themes accurately represented the participants' worldviews. (5) Exhaustive descriptions were integrat- 
ed from the results. (6) The exhaustive descriptions were summarised to formulate the fundamental structure of the phenomenon; and (7) In the study, trustworthiness was maintained through a number of processes. First the author collected all the data which ensured that similar questioning techniques were used. The utilisation of the thematic analysis approach ensured that themes were fully developed. Member checking - asking participants follow-up questions were undertaken as a way of confirming the themes and sub-themes generated during thematic analysis. This ensured that any gaps in the data were filled and the participants reviewed and confirmed the themes generated as a true representation of their worldviews.

A detailed audit trail was kept in ensuring that significant emphasis was placed on the methodological and analytical decisions made throughout the study and that the researcher critically reflected and evaluated the decisions made, with a reflection on decisions pertaining to key research methodology. This was undertaken by maintaining a log of all research activities, the development of memos, maintaining research journals, and documented all data collection and analysis procedures throughout the study. Also, this entailed the collection of raw data; data reduction and analysis notes; data reconstruction and synthesis products; the writing of process notes; materials related to intentions and dispositions; as well as preliminary development information. The examination of these sources of data facilitated better assessment as to whether the findings of the study are situated in the data, etc, and a reflection of how the study unfolded.

The data was managed with NVivo software version 11. In the process of data management. The analytical process proffered by Bazeley and Jackson (2014) was followed, using five (5) distinct steps. A project was created that comprised all the documents, coding data and related information that assisted in the process of data analysis while saving the NVivo project. The transcribed interview files were labelled. Qualitative data files were imported. Chunks of data were then coded. This included finding obvious themes as well as auto-coding. The codes formed a pattern. The passages of texts were compared and contrasted for ways in which they were similar and different. A thematic multi-case analysis was employed, the comparative concentration of which was on individual cases as well as the preservation of their uniqueness.

A chunk of data in the project document under a particular node was taken through the highlight of the requisite text using the mouse and pulling the highlighted text to the identified node using the coder. This included finding obvious themes as well as auto-coding. Subsequently, multiple codes were assigned to the 
same chunk of the texts including going through the same process. The codes formed a pattern. The passages of texts were compared and contrasted for ways in which they were similar and different. The emergent concepts, for example, were all retirement aspiration and paid work in retirement responses. As part of the final step, there was a review of the following: the start of the analysis, going further with concepts, categories and themes including narrative and discourse. Memos were used to tell the story of the research by adding descriptions. The knowledge developed from the data was reported.

The resultant activities were recorded in discussion memos. These strategies were integrated into the process of learning from the data. A thematic multi-case analysis was employed, the comparative focus of which was on individual cases including the preservation of their uniqueness. Miles and Huberman (1994) have succinctly expressed the goals of this type of analysis including generalisability.

The themes appeared as major findings and were used to create headings in the results section of the article. The interrelation between themes involved the use of narrative passage to convey the findings of the analysis. The themes were interconnected into a storyline. From these explorations, the researcher sought to understand how people construct meanings and actions, as preparations for understanding why people act the way they do (Charmaz 2006). The final step entailed the selection, filtering and viewing of the predefined report for the study.

\section{FINDINGS OF THE STUDY}

Tema in the Greater Accra region, Kasoa in the Central region and the Ashanti region were locked down due to the COVID-19 pandemic from March 30 ${ }^{\text {th }}$ to April $19^{\text {th }} 2020$. However, in the April $19^{\text {th }} 2020$, the lockdown was lifted after three weeks of its existence.

\section{Challenges}

The effects of the COVID-19 pandemic cut across socio-cultural, health and humanitarian dimensions. These have been articulated below. 


\section{Socio-cultural dimension}

Prior to the upsurge of the COVID-19 pandemic in Ghana, the study participants found themselves in a variety of living arrangements that ranged from living alone through living with a caregiver and a daughter and her family via to living with spouses. These have been exemplified as follows:

A week prior to the COVID-19 pandemic induced lockdown, my caregiver left for her parents', leaving me alone. As a result, my daughter arranged for me to go stay with my younger sister for a while because she was outside the region (Maamle).

I live alone so the lockdown further prevented me from receiving visitors even from my children (Ekow).

... because of my retirement from active service, I am a bit isolated from masses of people as used to be the case anyway. But with this COVID-19 pandemic's lockdown, this has been further compounded (Kofi Jones).

I have been living with my daughter and family ever since her first birth about four years ago. And so I have been with them before the emergence of the COVID-19 pandemic (Adzo).

I have lived alone for many years but than during the pandemic if I had fallen sick I'd have called my neighbours for support (Yaa Serwa).

The findings show that from the viewpoint of the experiences of the pandemic, it was also observed that on the one hand, the closing of schools made children available at home 24 hours per day, producing company and bonding between grandchildren and grandmothers, parents/guardians and children. This is indicative of firming up social relationships. From hindsight, this may have implications for children who may not see their school colleagues or class mates again due to the pandemic, resulting in negative social relations because of the propensity not to see friends and/or colleagues again. On the other hand, the role of the educational system in socialising children has been clearly articulated including the fact that it assists in providing parents and/or guardians to support them in terms of the number of man hours that are 
spent supervising little children (and/or school going children) as well as caring for them. This is a depiction of the sharing of childcare related workload(s) among teachers and parents and/or guardians. Noteworthy is that this has been a situation since time immemorial but it has become very critical particularly during the COVID-19 pandemic. It also seeks to bring to the fore the invaluable contribution of teachers and therefore schools to the upbringing of children worldwide. These facts have been demonstrated in the statements below:

I understand that the virus affects older individuals more and so my children were particular about that. More importantly when I was at my sister's, I was comfortable because she had 4 grandchildren who were at home due to the pandemic, and who kept me busy with grandma this, grandma that such that I never wanted to leave the place since I enjoyed the company of the little children so much (Maamle).

I was handling children between one month and 4 years old and so I was quite busy with such during the initial stages of the pandemic. My 4 year old grandson is a handful, he had started school long before the pandemic and having him at home full time was tedious, and I must confess a lot of work. The situation has been the same since March 2020 till date. He keeps me constantly on my toes (Adzo).

Arguably, parents have had these children and therefore it is their prerogative to spend time with them. The key challenge with this is the tedious nature of it.

The other issues of concern brought on board by the pandemic entail the fact that parents were more often than not, not at home with their children as has been the case prior to the emergence of the pandemic. However, with the pandemic, parents and/or guardians were at home to a large extent particularly because of the lockdown and the running of shifts at work places induced by the COVID-19 pandemic. It is on the basis of this that Asaaba intimates that:

My daughter was on maternity leave during this whole time up until somewhere in July 2020. But her husband had some time off during the pandemic, which was spent at home. Other than that they were very often out of the house due to which the little ones hardly saw them. He is often asleep either before 
they leave for or return from work. This situation was not made any better with the traffic situation in our vicinity.

The proceeding quote above alludes to the fact that the pandemic has provided the opportunity for parents to see and bond with their children, a situation that seemed impossible except for vacation periods on school calender(s). This is reflective of some form of positive experience as far as the pandemic is concerned. On the other hand, the pandemic resulted in truncating the educational system and trajectory of children for nearly a year, and which could have culminated in the loss of learning or enculturation moments.

The findings show that none of the study participants had to run errands for themselves because most of what had to be done such as shopping were done for them by significant others namely sister, daughter and husband among others. In addition, the participants stated that along with the closure of schools was the turn to the use of the internet by some grandchildren which if not supervised may turn out to be problematic. But the key concerns to some of the older adults are their immobility especially during the lockdown interspersed with issues of social or physical distancing as well as the propensity of child marriages in the case of the girl child. The following observations were made:

I was not going out during the period. Besides all purchases were done at the time by my sister and others (Maamle).

My daughter and her husband do all the shopping for the house (Adzo).

Because there is no schooling for now, anytime my granddaughter is free she is online chatting and surfing the net. That is not bad, but I think this has to be supervised (Jojo).

The effects of the pandemic for me is mostly the issue of immobility but for the girl child in particular, it is child marriage (Akuba).

The police are seen on the streets enforcing social distancing, decongestion, the wearing of masks and even on our screens (Fosu). 
Invariably, inasmuch as these voices are suggestive of the protection of the elderly from being infected with the coronavirus disease, it may be an indication of perhaps over dependence of older persons on significant others, thereby ascribing to them a 'vulnerable connotation. This may have implications for old age related dependency among study participants, thus barring attributes of self-reliance including what Nilsson et al. (2018) and Nilsson et al. (2021) denote as 'withdrawal from responsibility'.

\section{Health dimension}

From the viewpoint of health, the Ghanaian government's COVID-19 response strategies are to stop the importation of cases into the country via the closure of the nation's borders; containment of cases and slowdown spread; care for the sick - people with positive cases; minimisation of impact of pandemic related measures - financial issues supported by the Ministry for Gender, Children and Social Protection (MGCSP) minister; boost domestic capacity and self- reliance e.g. produce PPEs locally with implications for the well-being of older adults.

The study also shows that none of the study participants had contracted the coronavirus as at the time of data collection. They may have stayed clear of it for one reason or the other, despite the fact that they are older, bearing in mind that not eve-

rybody will be infected by the virus, notwithstanding the fact that the region of study - the Greater Accra Region is the most infested region in Ghana. Sam said:

I have high blood pressure but that has been kept under control. I was really worried on hearing that the COVID-19 pandemic affected older people most, predisposing them to their untimely deaths. That was all over on the news but I have narrowly escaped thus far. However, if there were to be any crisis or emergency regarding that I would have called my children to intervene (Sam).

\section{Humanitarian dimension}

The humanitarian dimension refers to the provisions made in aid of the vulnerable (or vulnerable groups) in the society such as older persons. This has become necessary because the pandemic has affected tens of thousands of people in diverse ways namely the loss of work, the lack of medical care and supplies as well as food supplies. At the global, national and local fronts, there are a myriad of organisations - e.g., Feeding America; No Kid Hungry, Meals on Wheels, the Seattle Foundation, 
the CDC Foundation, NYC organisations, Save the Children and a host of others working to ensure food, aid and medical supplies are provided to the needy in society.

Older people may have benefited from donations from all walks of life, however, the most directly related donation to them has been articulated in Table 2. These have been disaggregated as follows: Naro Aged Care (120 packages); Tobinco Foundation (150 packages); MaMere (50 packages); Mission 50Plus (Osu=50; Larteh=150; Akropong 150); 50 Plus and Counting SDA (100 packages); Arklifestyle (100 packages); James Town Elders (100 packages); and Association of Ghana Elders (AGE) for 8 organisations (500 packages) (C. Mate-Kole, personal communication, April 16, 2020). The above mentioned ageing based organisations on receiving these packages on behalf of the elderly, distributed them to older people. These are reminiscent of societal response to the effects of the pandemic. It is for this reason that Rudnickand (2020) argues that societies are measured in part in relation to how they rise to the occasion of collective crises.

Table 2

Donations distributed to the elderly

\begin{tabular}{|c|c|c|c|c|c|}
\hline Item \# & Organisation & Items & Ageing group & $\begin{array}{l}\text { Quantity } \\
\text { received }\end{array}$ & Source \\
\hline \multirow[t]{8}{*}{1.} & \multirow{8}{*}{$\begin{array}{l}\text { Centre for } \\
\text { Ageing Studies } \\
\text { in collaboration } \\
\text { with Minister/ } \\
\text { Ministry of } \\
\text { Finance }\end{array}$} & \multirow{8}{*}{$\begin{array}{l}1,470 \\
\text { food } \\
\text { packages }\end{array}$} & Naro Aged Care & 120 packs & \multirow{8}{*}{$\begin{array}{l}\text { Personal } \\
\text { communi- } \\
\text { cation }\end{array}$} \\
\hline & & & Tobinco Foundation & 150 packs & \\
\hline & & & MaMere & 50 packs & \\
\hline & & & Mission 50 Plus & $\begin{array}{l}350 \text { packs for } 3 \\
\text { organisations }\end{array}$ & \\
\hline & & & 50 Plus and Counting & 100 packs & \\
\hline & & & Arklifestyle & 100 packs & \\
\hline & & & Jamestown Elders & 100 packs & \\
\hline & & & $\begin{array}{l}\text { Association of Ghana } \\
\text { Elders (AGES) }\end{array}$ & $\begin{array}{l}500 \text { packs for } 8 \\
\text { organisations }\end{array}$ & \\
\hline
\end{tabular}

\section{Emerging issues}

In terms of emerging issues the study participants observed that because everybody is focusing on the disease and for his/her self and so accusing others is no longer 
the central focus, albeit in the short-term. Thus, the Ghanaian witch camps may not receive new entrants. They stated that:

I have observed that there has been a reduction in witchcraft accusations. Perhaps, it is because of the COVID-19 pandemic (Abeiku).

By and large, the challenges that older individuals experienced encompassed social isolation, loneliness (both existing including that intensified by the COVID-19 pandemic), immobility to socialise, tiredness beyond the ordinary level, inability to socialise among others.

\section{OLD PEOPLE'S COVID-19 PANDEMIC'S COPING MECHANISMS}

Two (2) main coping strategies were used by the elderly in this context, namely social coping and reactive coping.

\section{Social coping:}

Some of these social coping mechanisms are a bit restrictive especially that which bars older persons from going out to socialise and/or interact with their significant others mostly in terms of physical contact and/or being in crowded places. This may have implications for social isolation but this has also tempered with interaction through other means such as telephone calls, What's App, sleep or more relaxation and a host of others. This also entails listening to news on both television and radio. However, this conduit falls short of physical contact in addition to all the above but suffice it to say that it is so because the situation demands that. Significantly, staying indoors for the older people studied has become an alibi to the COVID-19 pandemic as they are of the preception that it is the only way to avoid being infected with the virus. It is for this reason that Akuba had been indoors during the whole COVID-19 pandemic. She has survived thus far by receiving food and medical supplies from her daughter and younger sister. Yaa Serwaa also lamented about her inability to attend church services with implication for her spirituality. The voices below show that:

I have stayed indoors throughout the duration of the COVID-19 pandemic up until now. In fact, I have not gone past the gate. I have always been inside. I 
basically interact with my daughter and the caregiver. Also, I receive frequent telephone calls from my children who are both outside and within the country. I rather listen to the news more by watching the television. I also chat on What's App. I also sleep more, well, because I have nowhere to go to under the circumstances (Kwamina).

I live with my younger daughter who runs errands for me and my younger sister too buys me food supplies and prepares meals for me. I hardly visit the salon to do my hair. I just do not want to contract the disease. You see, I do not visit others and no one too visits me. I prefer that. You know, we heard that older persons easily die from the disease and this is really discomforting. But so far, so good (Akuba).

I do not go out often except if I needed to purchase groceries and so I normally get to the market for those items that are needed. I do not even go to church anymore. This is a testament of the pandemic to my religious practices but you know, all shall pass (Yaa Serwaa).

I am more often than not on social media, especially Facebook, What'sApp and Twitter for news, information and hilarious depictions for chats from family and friends (Kwamina).

I became a full time nanny, keeping me busy, mobile and active (Adzo).

I resorted to the use of telephone conversations more these days (Maamle).

I often play videogames on the internet and make video calls in order to overcome boredom (Fosu).

I bump elbows with others presently, without necessarily shaking hands with them, which though is the traditional way of going about it (Jojo).

These kind of sedentary lifestyle have implications for other health challenges. 


\section{Reactive coping:}

This category of coping mechanism to the pandemic is related to undertaking an action that is intervention oriented. This kind of coping strategy served as a dual means of intervention, where the older person involved earns a token, keeps busy while filling the childcare gap created by the pandemic by virtue of the closure of schools, a great challenge to working mothers in particular. This has created an avenue for the nurture of school going children who thereby allow their parents the time to work including on shift basis. For instance: Essi says:

I live with my foster son and I am less engaged. In June 2020, a neighbour and a mother came to the house and asked if she could leave her son with me, go to work and return. I took the child and not long after that several other mothers brought their children for the same purpose. As a result, I now have about 20 children aged from 5 - 12 years, who are brought to me daily from Monday to Friday, and whom I care for and teach. I earn a token from this task.

These coping mechanisms can further be categorised into problem-focused and emotion-focused coping mechanisms. The problem-focused coping mechanisms on the one hand entail relaxation, telephone communication and/or conversations, listening to the news on television, chat on What'sApp, Facebook, Twitter, etc, make video calls as well as play videogames. Keeping busy, fill the childcare gap created by the pandemic, earn a meagre wage, social bonding with grandchildren, fending for and socialising children outside the traditional classroom environment and yet keeping them focused academically. Essi's resort to teaching and/or care for children is an indication or a demonstration of a degree of activity by way of not being a burden to society and therefore a depiction of active and successful ageing as posited by FUTURAGE (2011) and Blaakilda (2007) respectively. This may also be a reflection of individuals taking increased responsibility for governing themselves (Foucault, 2007; Sarasin, 2020).

Another angle to Essi's coping mechanism or activity is the need on the part of working mothers and/or parents to work in order to be able to cater for their families. Yet, COVID-19 responses in Africa have been documented as having unintended social consequences of exacerbated poverty, widespread hunger and food insecurity, as well as state and domestic violence (Divala, Burke, Ndeketa, Corbett, \& MacPherson, 2020). COVID-19-related disruptions may have lifelong implications for chil- 
dren and adolescents, given that these are sensitive developmental phases (Desmond, Sherr, \& Cluver, 2020) even the elderly in low- and middle-income countries with the most stringent restrictions. Indeed, Essi's coping techniques potentially shift the perspective on older persons from that of vulnerability and risk to strength and opportunities. This category of coping techniques lay emphasis on the significance of technology in contemporary times and periods of crisis such as the pandemic.

On the other hand, emotion-focused coping techniques pertain to social distancing, social isolation and loneliness. These seek to lessen the impact of the pandemic.

\section{DISCUSSION}

This study explored the lived experiences of older Ghanaian adults, the impacts of COVID-19 pandemic including coping strategies. These can be grouped into three categories namely: impact on social life and friendly relationships, impact on daily life and routines, and impact on health and well-being, and the results were considered on behalf of the biopsychosocial perspective (Engel, 1980).

The results show that age is not an unproblematic governing principle. Instead, in addition to protecting a vulnerable group, the age-based recommendation meant deprivation of previously assigned individual responsibility and, consequently, autonomy. It is shown how the participants handled this tension through varying degrees of compliance and resistance (and/or positive defiance).

The findings intimate that older persons were predisposed to socio-cultural, health and humanitarian dimensions of the effects of the COVID-19 pandemic, to which the lockdown was the major processor. These led to social isolation, immobility, the lack of social interaction and/or socialisation. These were coped with through the conduit of mass media, social media among others. Hence, Marston et al. (2020) argue that putting citizens in lock-down leaves them with psychological effects on a usually highly mobile population. Marston et al. (2020) maintain that older people's mobility is linked not just to destination, though that is important, but to a sense of identity, independence and freedom. Technology can help, if people have access to it and know how to use it. Technology complements day-to-day activities, leisure (e.g. videogames, streaming music and TV) (Dovie et al., 2019; Genoe et al., 2018), holidays (e.g. online booking of hotels, travel) and maintaining social connections 
via social media platforms (e.g. Facebook) as well as other communication platforms (e.g. What's App, Viber), (Dovie et al., 2019; Marston et al. 2020).

There are two (2) dimensions to technological use namely facilitators and distractors. Older people have been admonished to balance the facilitators of technological use (i.e. sharing of information and feeling secure) against the detractors of technology (i.e., feelings of apprehension of use, privacy, security). Marston et al. (2019) offered several recommendations that included the need for positive promotion of technology, focusing on the positive opportunities to improve one's health and well-being, creating peer support networks in relation to learning new technologies and how intergenerational relationships can be enhanced through technology.

Social media platforms such as Facebook (Dovie, 2019; Marston et al., 2020) can offer support for communities in times of crisis, such as COVID-19. For instance, a private Facebook group has been created for residents in Stony Stratford, a town on the outskirts of Milton Keynes with Facebook group membership of approximately 415 that enabled information to be shared across the community. Therefore, residents who may get COVID-19 infection are able to access support (e.g. groceries, collection of prescriptions), (Marston et al., 2020), while also ensuring the most vulnerable can be cared for. Additionally, this group offers its members a point of contact for sub-groups within this particular group; consisting of various streets which already have an existing communication/What's App group for communication and sharing of information. Each existing What's App group has a detailed/specific point of contact, which in turn may assist the respective residents to communicate within this digital connectivity neighbourhood. Existing What's App groups help to keep one another up to date with information and support. For instance, information such as downloadable leaflets on self-isolation has been shared by group members (Marston et al., 2020).

Stated differently, based on the global impact of COVID-19 on countries and communities alike, a myriad of technological devices have the propensity to provide a basis for maintaining social connections with friends, family, social networks and/ or the wider community. Evidentially, Marston et al. (2019) have established the fact that those who already have a social media account such as Facebook can chat with their friends. For those who did not have a social media account - and this includes both young and older adults had multiple ways of maintaining contact through the utilisation of a smartphone device with communication tools (App's) such as What's 
App. This suggests that social media platforms such as Facebook can offer support for communities in times of crisis, such as COVID-19 pandemic.

Beyond the dependence on family relations, social networks, technology can be used as a weapon in fighting against social isolation on condition that the elderly know how to use it or that they are technologically savvy (Dovie et al., 2019). Men and women are affected differently-older women are more likely to say they feel lonelier than older men (Dovie, 2019). What is essential is that during physical distancing sessions, older people should be able to access social connectedness and through technology. Per adventure, through this means there could be the monitoring of them in relation to their well-being and needs and health. The COVID-19 pandemic has reduced the rate of witchcraft accusations against older people. The disease has truncated prophesies against the elderly more or less.

Social isolation, among older adults has a higher likelihood of psychological and medical risks. The major risk factors entail the physical limitations that older persons are faced with, which have the propensity to impact mobility and their ability to do things by themselves (Norotney, 2019; Robbinson, 2019; Shaw, 2020). At best, these older people feel disconnected living on their own and not having support from relatives or social connection to others enshrined in the formation of friendships, involvement in regular social interactions, etc. Social isolation may also lead to loneliness and depression. It is worth stating that physiologically, loneliness and long-term social distancing may decrease the ability of a person to fight infection and inflammation (Hawkley, \& Cacioppo, 2010; Holt-Lunstad, 2020; Saladino, Algeri, \& Auriemma, 2020; Zabetakis, Lordan, Norton, \& Tsoupras, 2020). Strikingly, the stress and anxiety induced by loneliness cases may foster a change in white blood cells including the creation of more issues for older people. Social isolation can be perceived as a method targeted at improving public health but how can the adverse effects of social isolation be combated, especially in the elderly, during the COVID-19 lockdown? In terms of how to help older adults fight loneliness during COVID-19, it has been observed that social isolation can be dangerous for older adults (Jones, 2020). However, such can be assisted. According to Clifford Singer (2018) "we are a social species. Our social networks (i.e., families, tribes, communities, etc) enable us to survive and thrive". Yet studies (e.g. Heck, Frantz, Frizzo, François, Ludwig, Mesenburg, Buratti, Franz, \& Berlesi, 2021) have argued that insufficient social distancing may contribute to COVID-19 outbreak. 
Cities, towns and villages, and people at large revolve around various activities, from attending weekly church services to organising and attending funerals, going to the pub and cinema among others. These leisurely activities are their only connection with like-minded individuals, and possibly their own access to socialisation and communication. Keeping in touch by phone or video call will make a world of difference to them and show them that someone cares (Stubbings, 2020).

The study participants have also coped with the effects of the pandemic by selfisolating themselves. Bumping elbows as a way of greeting rather than shaking hands or kissing a cheek or two. Stories of panic buying, witnessing drones on the streets of Mediterranean cities, ghost trains into cities, and connecting with neighbours who in a previous time a nod of the head at best would have sufficed. Marston et al. (2020) opine that it should not be underestimated that many citizens with pre-existing mental health issues may start to experience greater anxiety, cabin fever and increased health related issues due to self-isolation. Yet, there has not been any news about prospective mental health issues arising from this pandemic, not only for those with pre-existing diagnosis but for those that do enjoy going to work, for those whose only contact and communication are with work colleagues. Most significant is the impact that the COVID 19 crisis has on the future of individuals and the health and social care services.

Police have been seen on the streets trying to enforce the COVID-19 pandemic laws in Ghana with force in lieu of attaining conformity. Marston et al. (2020) argue that the Brits do not have law enforcement or the military patrolling the streets, nor are there drones flying down and across streets, parks and highstreets in a bid to identify citizens breaching curfews or undertaking any unnecessary activities.

The COVID 19 virus is the cruellest stress test of institutional and individual health and social care activities. Institutionally, the health and care sectors rely heavily on adult family members (Hadley, 2015). However, the present study's findings show that social coping is social support based. Harnessing social support during the COVID-19 pandemic is a significant adaptation skill, which is consistent with Quadagno's (2014) articulation. Similarly, the provision of educational services to neighbours' children fills the knowledge gap in the country's schooling system due to COVID-19 pandemic. This serves as a new social role as well as a means of financial boasting. The ability to adapt to the impacts of the COVID-19 pandemic utilising social support and social role skills is reflective of social participation. Adaptation to COVID-19 challenges is therefore tantamount to fighting the associated isolation or 
loneliness ascertainable through “.... social networks (i.e., families, tribes, communities, etc) that enable older people to survive and thrive" (Singer, 2018). It is worth noting that the ability of the older adults to adapt to the effects of the COVID-19 pandemic is indicative of the pearls in the pandemic.

The study further outlined childcare modalities as an emergent factor. This child care arrangement aka learning alibi by mothers and/or parents is contrary to the argument by (Tetteh, 2005) that women will either be 'career oriented' or 'home oriented' (p.81). It also shows the integration of family life with work outside the home (Tetteh, 2005). According to Myers and Indriso (1986, pp. 26-27) childcare denotes "the process of attending to a child's basic need of shelter, protection, food, clothing and health". By contrast, the research found that childcare transcends these stipulations to encompass educational needs during this COVID-19 pandemic era. But prior to the pandemic, some of the childcare arrangements include taking the children to work; use of school facilities; children taken care of by informal caregivers namely househelps, grandparents, neighbours and a host of others (Tetteh, 2005). These are however used based on the specific needs of the mothers and/or parents involved.

It is imperative for parents and/or guardians to plan learning including nutritional routines (Zabetakis, Lordan, Norton, \& Tsoupras, 2020) for older adults including children and together have open conversations - take the time, protect children's online learning, stay in touch with children's educational facilities. This is because irresponsible parenting alongside with the COVID-19 pandemic are major setbacks to the fight against the menace of child marriages and teenage pregnancies. The economic hardship that the pandemic has exerted on people or couples with the closure of schools in the country could force children's parents to give off their children for marriage(s) as an alternative source of income for the family. Furthermore, child marriage and teenage pregnancy could thwart girl child development in particular, which in the longer term could affect the community and national development.

From a conceptual framework point of view, problem-focused coping is the point at which a person connects with the surrounding through direct activity, critical thinking, and dynamic fundamental leadership. Holland (2001) indicated that immediate action includes changing the circumstance/occasion or changing oneself to eradicate the stressors. In general, problem-focused coping procedures are planned for diminishing the anxieties of the circumstance or stressor as reflected in this paper via the impacts of the coronavirus disease. This is done by increasing the resources for managing the stressor (Lazarus \& Folkman, 1984). Consequently, prob- 
lem-focused stratagems and confident thoughtful techniques of coping are adaptive coping tactics that lessen stress experienced by individuals. Further, social isolation and social distancing are reminiscent of emotion-focused coping techniques which are planned for lessening the effect of the apparent stressor if the stressor cannot be changed or maintain a strategic distance from stressors (Lazarus \& Folkman, 1984) such as the COVID-19 pandemic. On the other hand, it has been argued that emotion-focused stratagems, for instance, evasion and negative thoughtfulness in light of a stressor are maladaptive strategies for coping. Even though these techniques for coping may diminish a person's feelings of anxiety, they encourage long-term wellbeing (Shaheen \& Alam, 2010). In summary, based on the adaptation of Engel's Biopsychosocial model (Engels, 1980) and Lazarus' (1993) coping theory, the positive and negative impacts of the COVID-19 pandemic on older people are presented, focused on their experiences, challenges, as well as the coping strategies identified.

\section{CONCLUSION}

This paper is an articulation of older adults' experiences and challenges of and coping against the COVID-19 pandemic in urban Ghana. Older adults were able to develop incredible resilience due to the adaptation strategies they resorted to. The adaptation strategies served as a better way to understand how older adults address difficulty in their social roles and daily activities. Significantly, rather than being victims, the study participants served as significant responders to the COVID-19 crisis by playing multiple roles in society, including as caregivers, educators, etc.

In conclusion, more reflection on and study of social and psychological/emotional challenges as well as underlying impact issues related to the current pandemic and more generally to global crises is needed. Older persons are at a disadvantage due to individual and structural discrimination, and they are more likely than their younger counterparts to be vulnerable to negative health outcomes.

It is therefore recommended that future research should explore the following: first, the experiences of older folks who were directly affected by COVID-19, second, ascertain the social change dynamics of COVID-19 on social institutions in Ghana and third, investigate mental health issues that may have been induced by the pandemic. 


\section{REFERENCES}

Bazeley, P., \& Jackson, K. (2014). Qualitative data analysis with Nvivo, (2 ${ }^{\text {nd }}$ ed.). Sage. Blaakilde, A. L. (2007). Löper Tiden från Kronos? Om Kronologiseringens Betydelse för Föreställningar om Ålder. [Time out for chronos? On the significance of chronology for notions of age]. In L, -E. Jönsson \& S. Lundin (Eds.), Åldrandets betydelser. Studentlitteratur, pp 25-51.

CDC (2020). Coronavirus disease 2019 (COVID-19). Retrieved September 1, 2020 from https://www.cdc.gov/coronavirus/2019-ncov/need-extra-precautions/ older-adults.html\#: :text=Help\%20at\%20Home-,The\%20risk\%20for\%20severe\%20illness\%20with\%20COVID\%2D19\%20increases\%20with,than\%20 people\%20in\%20their\%2050s.

Chanda-Kapata, P., Kapata, N., \& Zumla, A. (2020). COVID-19 and malaria: A symptom screening challenge for malaria endemic countries. Int. J. Infect Dis., 94, 151-153. https://doi.org/10.1016/j.ijid.2020.04.007

Charmaz, K. (2006). Constructing grounded theory. Thousand Oaks, CA: Sage.

Colaizzi, P.F. (1978). Psychological Research as the Phenomenologist Views It. In R. S. Valle, \& K. Mark (Eds.), Existential phenomenological alternatives for psychology. New York: Oxford University Press, 48-71.

De-Graft Aikins, A., Kushitor, M., Sanuade, O., Dakey, S., Dovie, D. A. \& KwabenaAdade, J. (2016). Research on aging in Ghana from the 1950s to 2016: A bibliography and commentary. Ghana Studies Journal, 19, 173-189.

De-Graft Aikins, A., \& Apt, N. A. (2016). Aging in Ghana: setting priorities for research, intervention and policy. Ghana Stud. J. 19, 35-45. https://doi.org/10.1353/ ghs.2016.0002

Desmond, C., Sherr, L., \& Cluver, L. (2020). Covid-19: Accelerating recovery. Vulnerable Children and Youth Studies, 1-6. https://doi.org/10.1080/17450128.2020.1 766731

Divala, T., Burke, R. M., Ndeketa, L., Corbett, E. L., \& MacPherson, P. (2020). Africa faces difficult choices in responding to COVID-19. The Lancet, 2019, 4539118. https://doi.org/10.1016/s0140-6736(20)31056-4 
Dovie, D. A. (2020). Articulation of the shallow inclusion and deep exclusion of older adults from the Ghanaian policy terrain. Public Policy Studies, 2(26), 59-85. https://doi: 10.33119/KSzPP/2020.2.3

Dovie, D. A. (2019). Leveraging social media induced visual culture for body image enhancement: The case of socialization in a contemporary society. Vista, (4), 117-152. https://doi.org/10.21814/vista.3018

Dovie, D. A., Dzorgbo, D.B.S., Mate-Kole, C.C., Mensah, H.N., Agbe, A.F., Attiogbe, A., \& Dzokoto, G. (2019). Generational perspective of digital literacy among Ghanaians in the 21st century: Wither now? Media Studies, 11(20). https://doi. org/10.20901/ms.10.20.7

Dovie, D. A., Ayimey, I.R., \& Adodo-Samani, P. (2018). Pension policy dimension to Ghanaian workers' housing needs provision. Interações: Sociedade e as Novas Modernidades, 35, 30-56. https://doi.org/10.31211/interacoes.n35.2018.a2

Engels, G. L. (1980). The clinical application of the biopsychosocial model. Am J. Pschiatry, 137(5), 535-44. https://doi.org/10.1176/ajp.137.5.535

Foucault, M. (2007). Security, territory, population. Lectures at the college de France, 1977-78. Palgrave Macmillan.

FUTURAGE. (2011). A road map for European ageing research. The University of Sheffield.

Genoe, R., Kulczycki, C., Marston, H.R., Freeman, S., Musselwhite, C., \& Rutherford, H. (2018). E-leisure and older adults: Findings from an international exploratory study. Therapeutic Recreation Journal, 52(1),1-18. https://doi.org/10.18666/ TRJ-2018-V52-I1-8417

Hadley, R. A. (2015). The case of the invisible older childless men. The fure of care: ILC-UK [Online]. http://bit.ly/2WBNTuV

Heck, T. G., Frantz, R. Z., Frizzo, M.N., François, C. H. R., Ludwig, M. S., Mesenburg, M. A., Buratti, G. P., Franz, L. B. B., \& Berlesi, E. M. (2021). Insufficient social distancing may contribute to COVID-19 outbreak: The case of Ijuí city in Brazil. PLOS ONE.

Hawkley, L. C., \& Cacioppo, J. T. (2010). Loneliness matters: A theoretical and empirical review of consequences and mechanisms. Ann Behav Med., 40(2). https:// doi.org/10.1007/s12160-010-9210-8 
Pearls in the COVID-19 pandemic: The case of older adults' lived experiences in Ghana

Holland, K. (2001). A study to identify stressors perceived by health science lecturing staff within a school at a South African University. http://hdl.handle.net/10413/5683

Holt-Lunstad, J. (2020). The double pandemic of social isolation and COVID-19: Cross-sector policy must address both. https://www.healthaffairs.org/ do/10.1377/hblog20200609.53823

Hsieh, S., Wu, M. \& Tang, C-H. (2016). Adaptive strategies for the elderly in inhibiting irrelevant and conflict no-go trials while performing the go/no-go task. Front. Aging Neurosci. https://doi.org/10.3389/fnagi.2015.00243

Jones, L. (1980). Great expectations: America and the baby boom generation. New York: Coward, McCann and Geoghegan.

Jones, X. R. (2020). Covid-19: An exposition, with a focus on social isolation in the elderly (UK) (Draft). figshare. Preprint. https://doi.org/10.6084/ m9.figshare.12022632.v2

Lazarus, R. S. (1993). Coping theory and research: Past, present, and future. Psychosomatic Medicine, 55, 234-247. https://doi.org/10.1097/00006842-19930500000002

Lazarus, R. S., \& Folkman, S. (1984). Stress, appraisal, and coping. New York: Springer.

Marston, H. R., Musselwhite, C., \& Hadley, R. (2020). COVID-19 vs social isolation: The impact technology can have on communities, social connections and citizens. Retrieved from https://ageingissues.wordpress.com/2020/03/18/covid19-vs-social-isolation-the-impact-technology-can-have-on-communities-social-connections-and-citizens/

Marston, H.R., Genoe, R., Freeman, S., Kulczcki, C., Musselwhite, C. (2019). Older adults' perceptions of ICT: Main findings from the technology in later life (TILL) study. Retrieved from https://www.mdpi.com/2227-9032/7/3/86

Miller, G. (2020). Social distancing prevents infections, but it can have unintended consequences. Retrieved from https://www.sciencemag.org/news/2020/03/weare-social-species-how-will-social-distancing-affect-us.

Miles, M. B., \& A. M. Huberman. (1994). Qualitative data analysis: An expanded sourcebook. Thousand Oaks, CA: Sage.

I G. (2020). How air pollution exacerbates Covid-19. BBC News. 
Musango, L., Nundoochan, A., \& Kirigia, J.M. (2020). The discounted money value of human life loss associated with COVID-19 in Mauritius. Frontiers in Public Health.

Myers, R. \& Indriso, C. (1986). Women's work and children. Paper prepared for Rockfeller Foundation workshop on issues related to gender, technology and development, Feb 26-27.

Nilsson, G., Ekstam, L., Axmon, A. \& Andersson, J. (2021). Old overnight: Experiences of age-based recommendations in response to the COVID-19 pandemic in Sweden, Journal of Aging \& Social Policy. https://doi.org/10.1080/08959420.2 021.1925042

Nilsson, G., Ekstam, L., \& Andersson, J. (2018). Pushing for miracles, pulling away from risk: An ethnographic analysis of the force dynamics at senior summer camps in Sweden. Journal of Aging Studies, 47(47), 96-103. https://doi. org/10.1016/j.jaging.2018.03.004

Novotney, A. (2019). The risks of social isolation. Monitor on Psychology, APA, 50(5), p. 32.

Oppong, C. (2006). Familial roles and social transformations: older men and women in sub-Saharan Africa. Res. Aging 28, 654-668. https://doi. org/10.1177/0164027506291744

Press conference (2020, March 16) Pressträff om covid-19 (coronavirus). https:// www.youtube.com/watch?v=n2MajAQvpY8

Quadagno, J. (2014). Aging and the life course: An introduction to social gerontology ( $6^{\text {th }}$ edition). McGraw Hill.

Rivera-Rodrigues, C., \& Urdinola, B. P. (2020). Predicting hospital demand during the COVID-19 outbreak in Bogota, Colombia. Frontiers in Public Health.

Robinson, S. (2019). Isolation has profound effects on the human body and brain. Here's what happens, s.l.: The Conversation, Science Alert.

Rothan, H. A., \& Byrareddy, S. N. (2020). The epidemiology and pathogenesis of coronavirus disease (COVID-19) outbreak. J Autoimmun, 109, 102433. https:// doi.org/10.1016/j.jaut.2020.102433 
Pearls in the COVID-19 pandemic: The case of older adults' lived experiences in Ghana

Rudnickand, A. (2020). Social, psychological, and philosophical reflections on pandemics and beyond. Societies, 10, 42. https://doi.org/10.3390/soc10020042

Saladino, V., Algeri, D. \& Auriemma, V. (2020). The psychological and social impact of Covid-19: New perspectives of well-being. Front. Psychol. https://doi. org/10.3389/fpsyg.2020.577684

Sarasin, P. (2020). Understanding the coronavirus pandemic with foucault? https:// doi.org/10.13095/uzh.fsw.fb.254

Schatz, E., \& Seeley, J. (2015). Gender, ageing and carework in East and Southern Africa: a review. Glob. Public Health 10, 1185-1200. https://doi.org/10.1080/174 41692.2015.1035664

Shaheen, F., \& Alam, S. (2010). Psychological distress and its relational to attributional styles and coping strategies among adolescents. Journal of the Indian Academy of Applied Psychology, 36(2), 231-238.

Shaw, N. (2020). 1.4 million in UK will be told to cut all social contact from Monday, Cardiff, Wales: Wales Online. 21.

Singer, C. (2018). Health effects of social isolation and loneliness. Journal of Aging Life Care, Spring 2018. https://www.aginglifecarejournal.org/health-effects-of-social-isolation-and-loneliness/

Singu, S., Acharya, A., Challagundla, K., \& Byrareddy, S. N. (2020). Impact of social determinants of health on the emerging COVID-19 pandemic in the United States. Frontiers in Public Health. https://doi.org/10.3389/fpubh.2020.00406

Sreeramareddy, C. T., Shankar, P. R., Binu, V. S., Mukhopadhyay, C., Ray, B., \& Menezes, R. G. (2007). Psychological morbidity, sources of stress and coping strategies among undergraduate medical students of Nepal. BMC Medical Education, 7.

Stubbings, L. (2020). Letter, written by the Chair of the NFWI in response to the current situation surrounding Coronavirus (COVID-19). https://twitter.com/ WomensInstitute/status/1239589253111111680/photo/1

Tetteh, P. (2005). We are managing: Childcare arrangements of working mothers in Accra. Legon Journal of Sociology, 2(2), 81-98. 
The Public Health Agency. (2020). Information till riskgrupper om covid-19 [Information for risk groups about covid-19]. Sweden: the Public Health Agency. https://www.folkhalsomyndigheten.se

UN (2020). Policy brief: The impact of COVID-19 on older persons. https://www. un.org/development/desa/ageing/wp-content/uploads/sites/24/2020/05/COVID-Older-persons.pdf

WHO (2020). Older people and COVID-19. https://www.who.int/teams/social-determinants-of-health/covid-19

Zabetakis, I., Lordan, R., Norton, C., \& Tsoupras, A. (2020). COVID-19: The inflammation link and the role of nutrition in potential mitigation. Nutrition, 12, 1466; https://doi.org/10.3390/nu12051466 